\title{
Implementation of Sustainable Development Concept in Hotel A Surabaya
}

\author{
Nuke Puspawardani, Kresno Eka Mukti, Angsar Nur Himawan, Happy Ratna Sentosa \\ Department of Architecture, Faculty of Civil Engineering and Planning, \\ Institute Technology Sepuluh Nopember Surabaya (ITS), Indonesia
}

\section{Article Info \\ Article history: \\ Received Dec 10, 2014 \\ Revised Feb 12, 2015 \\ Accepted Feb 26, 2015}

\section{Keyword:}

Eco-friendly

Hotel

Management

Sustainable

\begin{abstract}
Hospitality is one of the important sectors in the growth of the Indonesian Economy, which it continues to increase each year. But on the other hand it also has a negative impact. The higher use of the hotel, the higher the resource and energy expended to serve the guests of the hotel. This study aims to determine the implementation of sustainable development concept of Hotel A in Surabaya. This hotel is under auspices of the Accor Group, one of international hotel management groups, which already implemented the concept of sustainable development. To achieve the objectives of the study, the researcher using qualitative analysis techniques to process the primary and secondary data obtained, to find the answer on how far the application of sustainable development at the Hotel A. The research results show that Hotel A has conducted various measures to support sustainable development in several aspects. But they just apply 3 of 7 pillars of ecology as envisioned by the Accor Group. This study shows the aspects of eco-friendly management that can be carried out by a hotel.
\end{abstract}

Copyright (C) 2015 Institute of Advanced Engineering and Science. All rights reserved.

\section{Corresponding Author:}

Nuke Puspa,

Departement of Architecture,

Institute Technology Sepuluh Nopember Surabaya (ITS),

Campus ITS Keputih, Sukolilo, Surabaya 60111, East Java, Indonesia.

Email: arsitektur@its.ac.id

\section{INTRODUCTION}

Based on reports from the Ministry of Finance of Indonesia in 2012, the number of hotels has increased over the period 2009-2011. The number of hotels is 15283 units in 2011 or 4.8 percent compared to the year 2010 that as many as 14587 units. The number of guests also increased by $3.4 \%$ from 2010 with a total of 196679 people. Based on these data, could be said that hospitality is one of the important sectors in the growth of Indonesian economy. Although the growth of the hospitality industry could give a positive impact on the Indonesian economy, but it was also feared could have negative impacts on the environment. This is due to the higher utilization of the hotel, the higher the resource and energy expended to serve the guests of the hotel. It means that there are some environmental issues and sustainable development behind the growth of the hospitality industry in Indonesia.

According to Moreno et al, (2004), there are two main reasons behind the concern on environmental issues. First, people and government has realized that the hotel as commercial institutions have the financial resources and know-how, so the vision of the hotel should develop ecological solutions to environmental problems.

\section{THEORETICAL BACKGROUND}

Surabaya city vision is to become the Green City. The government of Surabaya has socialized ecofriendly building policies gradually since December 2013. The main target of this policy was the old 
buildings at the beginning of development have yet to implement the principles of green building. The "Green Building Awareness Award" (GBAA) program will be the highlight of the event was held by Surabaya's Government as an appreciation of the building managers participation in realizing the vision of "Surabaya as Green City" (Mufid, 2014). The program provides awards to the manager of the building or real estate buildings, such as hotels, apartments, shopping centers, and office buildings considered to implement the eco-friendly green building criteria (Riski, 2014).

Alexander, et al., in Pramod (2012) suggests three forms of the advantages of environmental management processes, namely; First, the energy savings can be made through the management of space heating and cooling systems, daily washing sheets, towels, flannels, tablecloths, linen and other, lighting by using a neon lamp that produces four times more light per watt than incandescent bulbs, and others. Second, water conservation driving hotels to manage water better, how and when water is used, pay attention to issues of water management in terms of both technical and operator, identifying where the excessive water use in shower, urinal, and others. third, solid waste management strategy in the hotel has many components, including paper, food, a variety of metal, plastic, aluminum, and glass. This program can create cost savings of waste transportation, creating a more eco-friendly hotel.

A hotel is under auspices of the Accor Group, one of international hotel management groups. It has already implement sustainable development concept, including the presence of 7 pillars of ecological environment as described in their official website www.accor.com/ sustainable development, they are:

\section{a. Health}

Health factors include about food, ranging where did we obtain food intake, how to process them until distribute the food to the consumer. An addition there are a hygiene factor and other factors that can threaten the availability of food. It's also an important issue to be considered the sustainability. Accor Group provides a healthy and hygienic food, not only for their guests but also employees.

\section{b. Nature \& Environment}

To preserve the environment, Accor Group has been participated in the preservation of habitats such as reducing water consumption and recycle the water that has been used be more useful. In addition there is a program to plant 3 million trees are fully supported by the United Nations as part of globally forests improvement process.

\section{c. Carbon Dioxide (CO2)}

The number of forest fires and disposal of wasted energy is one of the producers of $\mathrm{CO} 2$. It causes the greenhouse effect that could have an effect on world climate change. Therefore, the Accor Group has committed to the reduction of energy consumption.

\section{d. Innovation}

The integration relationship between sustainable concept with operation of the hotel procedurally make the Accor Group responds proactively to create new innovations and the development of existing innovation with the same purpose, creating a sustainable concept that shelters can be aligned and eco-friendly with the environment around it.

\section{e. Locality}

In addition to natural factors, local factors between communities and local governments have contributed to be important issues considered by management. The Accor Group realized that they become "guests" for housing around it, so that local factors and the culture of local community will be considered in their sustainability concept.

\section{f. Employees / workers}

Employees are one important thing that is also recognized by the management in addition to environmental factors. Without them, concepts and operations of a hotel will not be able to run. Hence, the Accor Group committed to help their employees to develop their skills and ability by conducting some training, seminar or any reward to appreciate their hard work.

\section{g. Communication}

With several commitments promised by the Accor Group, the existence of good communication between management, their own employees, some franchises and suppliers is something that is not less important. Thus each party will be aware of and understand and expected to keep up their concepts and strategies.

As an international standard hotel, interesting to know whether the hotel has adopt the green hotel concept as described above. Moreover, Surabaya also has a vision to be a green city. Therefore, this study aims to determine the implementation of sustainable concept at Hotel A.

Based on the history of a hotel which has been built in 1995 (environmental issues are increasingly so much discussion until now), and the front view of the building, it was possible that Hotel A has implemented eco-friendly concept on its operation. But if it linked by Accor Groups's seven pillars of ecological environment concept which has been described above, Hotel A may still have yet to implement the whole pillar. 


\section{RESEARCH METHOD}

\subsection{Types of Research}

This study used a qualitative descriptive approach. Qualitative method is certain traditions in the social sciences fundamentally depend on the human observations and associated by such persons in the language and the term Kirk \& Miller in Nasution (1988). In addition, qualitative research is descriptive in which the process and meaning (subject perspective) is highlighted in the study, but the theoretical background is used as a guide in order to focus of the research accordance with the facts in the reality.

The purpose of descriptive research is research intended to gather information about the status of an existing symptoms, namely the state of symptoms according to what it is at the time of the study (Suharsimi Arikunto: 2005). The aim of the research is descriptive, it means to create a systematic explanation, factual, and accurate information on the facts and properties of the population or a particular area.

\subsection{Methods of Data Collection}

The process of data collection can be defined as a process or activity conducted by researchers to uncover or capture a variety of phenomena, information, or condition of reasearch area appropriate with the scope of the research study. Research data collection using primary and secondary data collection. The primary method of data collection conducted by direct observation and go directly to the field and towards the management of the hotel. While the secondary survey conducted to obtain data, written information from the hotel and website. In this way the information needed in the research can be obtained.

\subsection{Analysis Method}

In this study used qualitative analysis techniques. Qualitative analysis is the analysis carried out without any mathematical calculations and conclusions from the observations will be the results of the analysis. The analytical methods used to process data obtained from the results of secondary survey to achieve the objectives of the research. The analysis is used to assist in providing the best option of real conditions, as well as to provide a broad understanding of a concept that will be executed.

There are two analysis will be discussed in the stage of analysis, namely analysis of the design of Hotel A building with Sustainability Analysis of Hotel A itself. Both of analysis was conducted by descriptive-qualitative. This analysis technique is an analytical tool describing or explaining the observed data without statistical testing. This analysis is used to describe the characteristics of a sample or population observed and can be described by table and image

\section{RESULT AND DISCUSSION}

There are two analysis will be discussed in this study, they are analysis of design and analysis of the sustainability of Hotel A. Dimensional space at Hotel A divided into 5 classifications, ie public areas, guest room area, administration area, service area, and circulation areas. While for activity in the room at Hotel A is divided into two, time-based activities and activities based on the building users. Time-based activities can be seen from the activities of the employee A divided into three shifts, the morning shift (7:00 to 3:00 p.m.), the afternoon shift (15:00 to 22:00), and the night shift (22:00 to 7:00 a.m.). While user building-based activities is divided into guest activities and hotel management activities. Guest activities are divided into two, guests who have stayed with activities such as sleeping, bathing, eating, drinking, meetings, seminars, sports; as well as guests who are not staying with activities such as appointments, meetings, and seminars. Meanwhile manager of hotel activity is divided into two, the non-technical managers (front and rear) as well as the technical managers. Non-technical managers in front service registration, providing information, serving storage key and goods, arranging reservations, manage room equipment, and handle visitors payment. eanwhile rear non-technical managers Meanwhile non-technical managers in charge of managing and arranging hotel management, overseeing the financial system flows and hotels, and supervise all hotel operations.

\subsection{Analysis of Design}

Design analysis is divided into two, functionally and aesthetics. Viewed from the functional design, Hotel A Surabaya has several aspects that affect the functional value that is the plan as well as the facade of the hotel building. In the layout and landscape, spatial planning at a hotel is quite effective and efficient, there is a hierarchy and obvious space zoning, so the flow circulation of space users can be organized. In semiotics is quite effective because each area and the room had a sign respectively. However, there are some lacks in the organization of motorcycle parking area. Entry-exit flow circulation of vehicles are not distinguished so it can cause a collision flow especially if the volume of vehicles in and out are high.

There are many openings in the facade of Hotel A building, where most part of the building facing east. It can result in the most of the buildings get sun all day, so the use of electricity for lighting can be 
minimized. In addition, there are some hotel facilities are placed outdoor, it means those facilities only use natural lighting as well weather. It's appropriate with third aspect of the seven pillars of the ecological environment, which carried by Accor Group, the carbon aspect.

The next step of the analysis is aesthetic design generally. Hotel A Surabaya brings the concept of hotel that offers a resort ambience in the middle of urban. It can be viewed from the extent of open land over growning with various kinds of plants so the natural ambience feels very thick like being at a resort. The concept is suitable with the second aspect of the 7 pillars of ecological environment, natural and environmental aspects. Then it's combined with tropical modern style, in which one of the character is there are terrace in every room, and form a sloping tiled roof. While on the front facade of the building is quite unique by applying colonial architectural styles, which it can attract the attention of the public. Concerning interior design, Hotel A Surabaya apply eclectic style, there are a mix of various styles for different spaces. Moreover, design of the rooms using modern style. It can be understood as one of the major markets for Hotel A is nowadays businessmen, are likely requires more of practicality. While for the lobby, likely to use a unique contemporary design. It may to give a first impression for consumers and prospectively consumers of the hotel.

\subsection{Sustanaibility Design}

There are several aspects to be discussed in the analysis of sustainability. The first aspect is social capital. Social capital found in Hotel A Surabaya has two types of interaction, internal and external interactions. Internal interactions occurred between employees and hotel managers through family gathering activities are held, while the external interactions occurred between employees and ballroom tenants leased by the hotel. The second aspect is economic capital. Economic capital at Hotel A can be seen from the number of economic activities occured. The main economic activity is leasing the rooms. In addition to leasing the rooms, the income also derived from selling food in the Hotel A's restaurant.

The third aspect is ecological capital. Accor Group offers the concept of the use of the seven pillars in conducting sustainable development, consisting of promoting the health, environmental sustainability, reduce the effects of carbon, always innovate, utilizing local resources, equip workers/ employees of the hotel, and the last one is began to act against global warming.

Of the seven pillars that are applied by the Accor Group, Hotel A Surabaya still not apply the concept optimally as they only use three of the seven pillars, they are put forward the health, preservation of nature, and reduce the effects of carbon. So, it can be concluded that Hotel A Surabaya is still not good in implementing sustainable development. The latter aspect in the analysis of sustainable development is infrastructure capital. The infrastructure found on Hotel A have been classified as very complete where the guests have been served by electricity and clean water infrastructure well. For electricity infrastructure, Hotel A has a useful backup diesel engine as a source of power if the power grid in the area of hotel impaired. For waste treatment at Hotel A still not managed in accordance with the procedures of Hotel A in general. On Planet 21 program, there are a point that the waste will be recycled, but this isn't carried out by Hotel A Surabaya. For accessibility towards Hotel A can be considered as easy because it lies on the side of the road classified as primary artery so definitely a lot of vehicles passing across Hotel A.

This sustainability discussion get into pillars of sustainability environmental and reducing carbon due to the preservation of nature the sustainability will be achieved well, and then reducing the carbon can save energy.

\section{CONCLUSION}

As mentioned in the analysis, Hotel A has conducted various measures to support sustainable development in several aspects. Hotel A has made savings in lighting and water use aspects according to the theory of environmental management mentioned by Alexander, et al., (2002). But if it is associated with the concept of seven pillars of ecological environment by the Accor Group, Hotel A Surabaya just apply 3 of 7 pillars of ecological environment, they are the first pillar (health), second pillar (nature and environment), and third pillar (carbon dioxide). Further research may be required to determine the benefits that can be obtained by Hotel A if they are able to apply the 7 pillars ecology.

\section{REFERENCES}

[1] Kirk Jerome and Miller Marc L, "Reliability and Validity in Qualitative Research," Beverly Hills, CA: Sage Publication, INC, 1986.

[2] Arikunto, Suharsimi, "Manajemen Penelitian," Cetakan Ketujuh, Penerbit Rineka Cipta, Jakarta, 2005.

[3] Sulipan, "Penelitian Deskriptif Analisis 'Berorientasi Pemecahan Masalah".

[4] http://www.novotel.com . Diakses pada tanggal 9 Desember 2014. 


\section{BIOGRAPHIES OF AUTHORS}
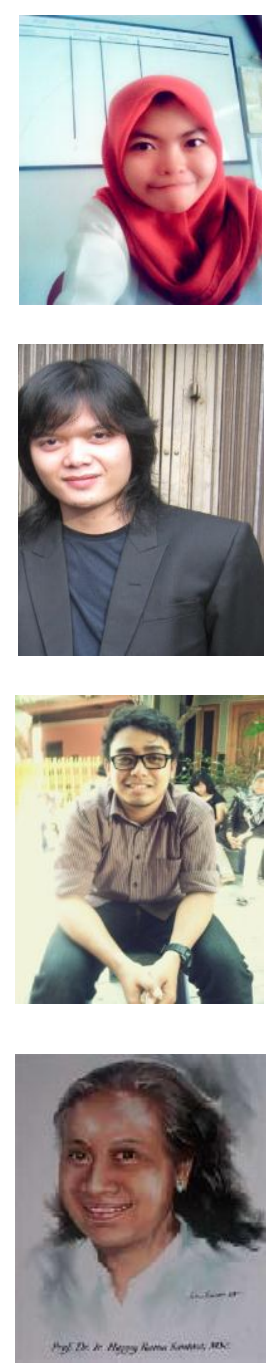

Nuke Puspa was born in Surabaya, March 30, 1988, was the first of second brothers. The author has taken formal education that SDN Ngagel Rejo I Surabaya, SMP 12 Surabaya, SMAN 5 Surabaya. After graduating from SMAN 5 Surabaya in 2006, the author follows the college entrance examination through the UMPTN Program - and received in the Department of Architecture FTSP - ITS in 2006, and graduated in 2010. Now the author pulish this journal as a student of Real Estate Program Master.

Kresno Eka Mukti was born in Surabaya, Mei 13, 1991, was the first of second brothers. The author has taken formal education that MIN I Malang, SMP 12 Malang, SMAN 3 Malang. After graduating from SMAN 3 Malang in 2009, the author follows the college entrance examination through the UMPTN Program - and received in the Department of Interior Product FTSP - ITS in 2009, and graduated in 2013. Now the author pulish this journal as a student of Real Estate Program Master.

Angsar Nur Himawan was born in Surabaya, August 21, 1992, was the second of three brothers. The author has taken formal education that SDN Kepuh Kiriman I Surabaya, SMP 12 Surabaya, SMAN 18 Surabaya. After graduating from SMAN 18 Surabaya in 2010, the author follows the college entrance examination through the Partnership Program - Independent and received in the Department of Urban and Regional Planning FTSP - ITS in 2010, and graduated in 2014. Now the author pulish this journal as a student of Real Estate Program Master.

Prof. Dr.Ir. Hj Happy Ratna MSc is a lecturer/profesor in the department of Architecture, ITS, Indonesia since 1976 and Head of The Laboratory for Housing and Human Settlements ITS. She is also lecturer in Architectural Design, Human Settlement and Environment, Sustainable Development, Human Settlement in Urban Development and Research Methodology. Also supervisors for undergraduate final Project Design, thesis for Master Degree and PhD student's dissertation. 